\title{
Synthesis, Characterization and Antimicrobial Activities of Sulfadiazine Schiff Base and Phenyl Dithiocarbamate Mixed Ligand Metal Complexes
}

\author{
Benjamin Chibuzo Ejelonu', Sulaiman Adeoye Olagboye ${ }^{2}$, Oluwatoba Emmanuel Oyeneyin 1*, \\ Oladipo Adebayo Ebiesuwa ${ }^{1}$, Oluwatomisin Emmanuel Bada1 \\ ${ }^{1}$ Department of Chemical Sciences, Adekunle Ajasin University, Akungba Akoko, Nigeria \\ ${ }^{2}$ Department of Chemistry, Ekiti State University, Ado Ekiti, Nigeria \\ Email: *emmanueltoba90@gmail.com
}

How to cite this paper: Ejelonu, B.C., Olagboye, S.A., Oyeneyin, O.E., Ebiesuwa, O.A. and Bada, O.E. (2018) Synthesis, Characterization and Antimicrobial Activities of Sulfadiazine Schiff Base and Phenyl Dithiocarbamate Mixed Ligand Metal Complexes. Open Journal of Applied Sciences, 8, 346-354.

https://doi.org/10.4236/ojapps.2018.88026

Received: July 17, 2018

Accepted: August 25, 2018

Published: August 28, 2018

Copyright $\odot 2018$ by authors and Scientific Research Publishing Inc. This work is licensed under the Creative Commons Attribution International License (CC BY 4.0).

http://creativecommons.org/licenses/by/4.0/

\begin{abstract}
Sulfadiazine Schiff base and Phenyl dithiocarbamate mixed ligand metal complexes have been synthesized and characterized. The characterization of metal complexes is based on the results of the solubility, colour, melting points and elemental analysis as well as the spectroscopic studies. The results obtained from the spectroscopic spectra revealed from the UV-visible showed the presence of chromophoric groups while the FTIR results confirmed that the metals coordinated through the two nitrogen atoms of Sulfadiazine Schiff base and sulphur atom of the N-phenyl dithiocarbamate. Also the antimicrobial activities of the metal complexes proved that the metal complexes are more active than the parent ligands.
\end{abstract}

\section{Keywords}

Sulfadiazine Schiff Base, Phenyl Dithiocarbamate, Metal Complexes, Antimicrobial Activities, Spectral Studies

\section{Introduction}

Coordination compounds exhibit different characteristics properties which depend on the metal ion to which they are bound, the nature of the metal as well as the type of ligand etc. These metal complexes have found extensive application in various fields of human interest [1]. Schiff bases play important roles in coordination chemistry as they easily form stable complexes with most transition 
metal ions [2]. Schiff base complexes have remained an important and popular area of research due to their simple synthesis, versatility, and diverse range of applications [2] [3]. Sulfadiazine Schiff base is formed from the reaction of sulfadiazine and salicylaldehyde. Sulfadiazine is a useful antibacterial drug with a typical sulfonamide structure. Salicyaldehyde is an organic compound described as a key precursor to variety of chelating ligand by condensation with amines [4].

Schiff bases derived from an amino and carbonyl compound are an important class of ligands that coordinate to metal ions via azomethine nitrogen and have been studied extensively [5] and reported for their antimicrobial, anti-inflammatory, antitumor, anticancer, antimalarial and anticonvulsant activity [6]. Metal complexes of $\mathrm{N}$-phenyl dithiocarabamates are widely studied due to their biological, chemical, agricultural and industrial applications. The presence of the dithiocarbamate moiety in some biologically active molecules has necessitated interest in their potentials for medical application [7].

At present, due to increase in resistance to current generation of antibiotics, efforts are being made to develop novel chemotherapeutic targets. Development of metal based pharmaceutical has received tremendous attention [8] [9] [10]. This work was therefore designed to synthesize, characterize and evaluate the antimicrobial activities of Sulfadiazine Schiff base and N-phenyl dithiocarbamates mixed ligand metal complexes.

\section{Experimental}

\subsection{Materials and Methods}

All reagents used were of analytical grade. All chemicals were obtained from Sigma-Aldrich. All the reagents, starting materials as well as solvents were purchased commercially and used without any further purification. The melting points were recorded in melting point apparatus. Elemental $\mathrm{C}, \mathrm{H}, \mathrm{N}$ and $\mathrm{S}$ analysis were carried out on a Fison EA 1108 Micro analyzer. The Infrared (FTIR) spectra were recorded by using FTIR, 8300 Shimadzu spectrophotometer in the frequency range of $4000-400 \mathrm{~cm}^{-1}$. The ultraviolet-visible (UV-vis) spectra were recorded by using Shimadzu UV-VIS. 160A ultra-violet spectrophotometer in the range of $200-800 \mathrm{~nm}$.

\subsection{Synthesis of Metal Complexes}

The sodium salt of the Sulfadiazine Schiff base was generated from sodium hydroxide and Sulfadiazine Schiff base according to the following equation:

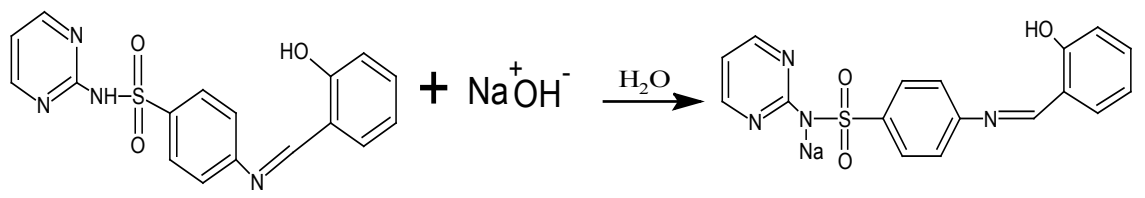

Sodium salt of sulfadiazine schiff base ligand 
$1.00 \mathrm{mmol}$ (0.3704 g) sulfadiazine ligand was dissolved and stirred in 30.00 $\mathrm{ml}$ deionized water for ten minutes, this was followed by $1.00 \mathrm{mmol}(0.0403$ g) $\mathrm{NaOH}$ in $20 \mathrm{ml}$ deionized water and the mixture was stirred for one hour. $1.00 \mathrm{mml}$ metal salt $\left(0.1298 \mathrm{~g} \mathrm{CoCl}_{2} 6 \mathrm{H}_{2} \mathrm{O} 0.2280 \mathrm{~g} \mathrm{CuCl}_{2} \cdot 2{ }_{2}{ }_{2} \mathrm{H}_{2} \mathrm{O}\right.$, and $0.2920 \mathrm{~g}$ $\mathrm{Ni}\left(\mathrm{NO}_{3}\right)_{2} \cdot 2 \frac{1}{2} \mathrm{H}_{2} \mathrm{O}, 0.1363 \mathrm{~g} \mathrm{ZnCl}_{2}, 0.2280 \mathrm{~g} \mathrm{CdCl}{ }_{2} \cdot 2 / \mathrm{H}_{2} \mathrm{O}$ respectively) dissolved in $30 \mathrm{~cm}^{3}$ was gently added to the mixture while stirring continued for two hours. Finally, $1.00 \mathrm{mmol}$ (0.1860 g) aniline dithiocarbamate ligand dissolved in $30 \mathrm{~cm}^{3}$ was added to the mixture. The resulting mixture was then allowed to stir for 3 hours. The precipitate formed was filtered, washed with deionized water, and the residue kept in a clean crucible and dried over silica gel in a dessicator.

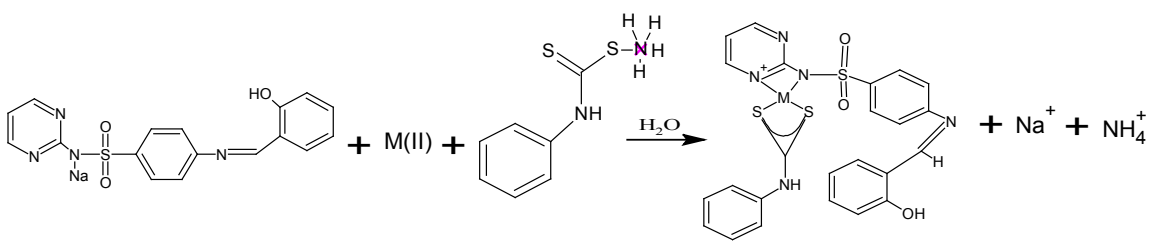

Formation of metal complex from sulfadiazine schiff base and N-phenyl DTC

Note: $\mathrm{M}=\mathrm{Co}, \mathrm{Ni}, \mathrm{Cu}, \mathrm{Zn}$ and $\mathrm{Cd}$.

\subsection{Antimicrobial Studies of the Ligands and Their Metal Complexes}

Ten different bacteria and ten fungi were collected from University of Ife Teaching Hospital, Ile-Ife, Osun state, Nigeria. They were sub-cultured on nutrient agar for bacteria and potato dextrose agar for fungi. Both media were prepared according to manufacturer's specifications. True representatives of each of the different organisms were sub-cultured, their identification and taxonomic studies were carried out to confirm each organism. The confirmed organisms were then prepared for use as test organisms for the antibiotic susceptibility test. Each of the test organisms was transferred to a liquid medium nutrient broth for bacteria and enriched peptone broth for fungi. They were inoculated for $18 \mathrm{~h}$ after which they were used for the test.

Mueller-Hinton agar was prepared according to manufacturer's specification, poured into petri dishes and allowed to set. Sterile swab were then used to seed the set agar plates with each test organism, then an $8 \mathrm{~mm}$ diameter cork-borer was used to bore wells in the plates, after which each wells was filled with the solution of each test compound.

\section{Results and Discussion}

\subsection{Elemental Analysis}

Elemental analysis of the metal complexes was determined to correlate between the calculated and experimental values of the percentage compositions of carbon, hydrogen, nitrogen and chloride as contained in the metal complexes (Table 1). 
Table 1. Elemental analysis of metal complexes.

\begin{tabular}{|c|c|c|c|c|c|c|c|}
\hline Metal complex & Colour & $\begin{array}{c}\% \\
\text { yield }\end{array}$ & M. $\mathrm{pt}^{\circ} \mathrm{C}$ & $\mathrm{C}$ & $\mathrm{H}$ & $\mathrm{N}$ & $\mathrm{Cl}$ \\
\hline [Co(II)(SD)PhDTC] & Dark & 54 & 295 & $\begin{array}{c}44.86 \\
(45.13)\end{array}$ & $\begin{array}{l}2.933 \\
(3.28)\end{array}$ & $\begin{array}{c}10.15 \\
(10.26)\end{array}$ & $\begin{array}{c}21.44 \\
(20.96)\end{array}$ \\
\hline$[\mathrm{Ni}(\mathrm{II})(\mathrm{SD}) \mathrm{PhDTC}]$ & $\begin{array}{c}\text { Dark } \\
\text { brown }\end{array}$ & 62 & 273 & $\begin{array}{c}43.35 \\
(43.75)\end{array}$ & $\begin{array}{c}3.55 \\
(3.28)\end{array}$ & $\begin{array}{c}10.56 \\
(11.08)\end{array}$ & --- \\
\hline$[\mathrm{Cu}(\mathrm{II}(\mathrm{SD}) \mathrm{PhDTC})$ & $\begin{array}{c}\text { Dark } \\
\text { brown }\end{array}$ & 59 & 290 & $\begin{array}{c}42.36 \\
(43.70)\end{array}$ & $\begin{array}{c}3.77 \\
(3.96)\end{array}$ & $\begin{array}{c}10.57 \\
(11.64)\end{array}$ & $\begin{array}{c}21.22 \\
(20.61)\end{array}$ \\
\hline [Zn(II)(SD)PhDTC] & Colourless & 64 & 248 & $\begin{array}{c}49.08 \\
(49.11)\end{array}$ & $\begin{array}{c}3.80 \\
(3.24)\end{array}$ & $\begin{array}{c}11.88 \\
(11.94)\end{array}$ & $\begin{array}{c}1643 \\
(16.37)\end{array}$ \\
\hline [Cd(II)(SD)PhDTC] & $\begin{array}{l}\text { Milky } \\
\text { yellow }\end{array}$ & 57 & 260 & $\begin{array}{c}45.45 \\
(45.47)\end{array}$ & $\begin{array}{c}3.22 \\
(3.00)\end{array}$ & $\begin{array}{c}11.31 \\
(11.05)\end{array}$ & $\begin{array}{c}15.91 \\
(15.16)\end{array}$ \\
\hline
\end{tabular}

\subsection{Solubility}

All synthesized ligands and their corresponding metal complexes show appreciable solubility in dimethyl sulphoxide (DMSO) and other organic solvents such as ethanol, diethyl ether, acetone, propan-2-ol, among others. This finding suggests that the metal complexes are basically non-polar compounds (Table 2).

\subsection{UV/Vis Absorption}

The UV-Vis electronic spectra of the ligands and corresponding metal complexes were recorded in dimethyl sulphoxide between $2000 \mathrm{~nm}$ at room temperature. The electronic spectra of the synthesized metal complexes and the ligands are shown in Table 3 . In the electronic spectra of the $\mathrm{Co}(\mathrm{II}), \mathrm{Ni}, \mathrm{Cu}(\mathrm{II})$, $\mathrm{Cd}(\mathrm{II})$, complex shown in the table, three bands were observed. The complex showed a sharp peak of high intensity at $390 \mathrm{~nm}$ and the broad peaks at 412 and $500 \mathrm{~nm}$ respectively. When compared with those of the free ligands, it is evident that the peaks at $370,340,251$ and $250 \mathrm{~nm}$ all shift to higher wavelengths indicating the chromophoric group of the ligands is involved in bonding with the metal ions in the complexes [11].

In the electronic spectra of the Co(II) complex shown in the table, three bands were observed. The complex showed a sharp peak of high intensity at $480 \mathrm{~nm}$ and broad bands at 500 and $600 \mathrm{~nm}$ respectively. When compared with those of the free ligands, we observe that the peaks at 370, 340, 251 and $250 \mathrm{~nm}$ all shift to higher wavelengths indicating the chromophoric group of the ligands is involved in bonding with the metal ions in the complexes [12] [13]. On the other hand, $\mathrm{Zn}(\mathrm{II})$ complex did not so any sign of absorbance, indicating no d-d transition for being colourless [14].

\subsection{FTIR}

From the FTIR data table, the bands shown at 1588, 1592 and $1580 \mathrm{~cm}^{-1}$ on careful comparison were assigned to $\mathrm{v}(\mathrm{N}-\mathrm{H})$ vibration of primary or secondary amines or amides. The bands corresponding to the $\mathrm{v}(\mathrm{C}-\mathrm{S})$ vibration show absorption at 1081, 1085 and 1090,1088, 1092 and $1031 \mathrm{~cm}^{-1}$ in the ligand and 
Table 2. Solubility tests of the ligands and mixed ligand metal complexes.

\begin{tabular}{|c|c|c|c|c|c|c|c|}
\hline Solvent & $\begin{array}{l}\text { Sulfadiane } \\
\text { Schiff base }\end{array}$ & $\begin{array}{c}\text { N-pheyl } \\
\text { DTC }\end{array}$ & $\begin{array}{c}\text { Co(II) } \\
\text { Complex }\end{array}$ & $\mathrm{Ni}(\mathrm{II})$ & $\mathrm{Cu}(\mathrm{II})$ & $\mathrm{Zn}(\mathrm{II})$ & $\mathrm{Cd}(\mathrm{II})$ \\
\hline Water & Soluble & $\begin{array}{c}\text { Sparingly } \\
\text { Soluble }\end{array}$ & Insoluble & Insoluble & Insoluble & Insoluble & Insoluble \\
\hline Toluene & $\begin{array}{l}\text { Sparingly } \\
\text { Soluble }\end{array}$ & $\begin{array}{c}\text { Sparingly } \\
\text { Soluble }\end{array}$ & $\begin{array}{l}\text { Sparingly } \\
\text { Soluble }\end{array}$ & Insoluble & Insoluble & Soluble & Soluble \\
\hline Chloroform & $\begin{array}{l}\text { Sparingly } \\
\text { Soluble }\end{array}$ & $\begin{array}{c}\text { Sparingly } \\
\text { Soluble }\end{array}$ & $\begin{array}{l}\text { Sparingly } \\
\text { Soluble }\end{array}$ & $\begin{array}{c}\text { Sparingly } \\
\text { Soluble }\end{array}$ & $\begin{array}{c}\text { Sparingly } \\
\text { Soluble }\end{array}$ & Soluble & Soluble \\
\hline Ethanol & Soluble & Soluble & $\begin{array}{l}\text { Partially } \\
\text { Soluble }\end{array}$ & $\begin{array}{c}\text { Sparingly } \\
\text { Soluble }\end{array}$ & Soluble & Soluble & Soluble \\
\hline Xylene & $\begin{array}{l}\text { Sparingly } \\
\text { Soluble }\end{array}$ & $\begin{array}{c}\text { Sparingly } \\
\text { Soluble }\end{array}$ & $\begin{array}{l}\text { Sparingly } \\
\text { Soluble }\end{array}$ & Insoluble & $\begin{array}{l}\text { Sparingly } \\
\text { Soluble }\end{array}$ & $\begin{array}{c}\text { Sparingly } \\
\text { Soluble }\end{array}$ & Soluble \\
\hline Diethylether & Soluble & Insoluble & Soluble & Soluble & Soluble & Soluble & Insoluble \\
\hline DMSO & Soluble & Soluble & Soluble & Soluble & Soluble & Soluble & Soluble \\
\hline Acetone & Soluble & Soluble & Soluble & Soluble & Soluble & Soluble & Insoluble \\
\hline
\end{tabular}

Table 3. Spectroscopic studies of metal mixed ligand complexes.

\begin{tabular}{cccccccc}
\hline & $\lambda_{\max }(\mathrm{nm})$ & \multicolumn{7}{c}{ IR spectrum $\mathrm{cm}^{-1}$} \\
\hline COMPLEXES & & $\mathrm{v}(\mathrm{S}=\mathrm{O})$ & $\mathrm{v}(\mathrm{N}-\mathrm{H})$ & $\mathrm{v}(\mathrm{C}-\mathrm{S})$ & $\mathrm{v}(\mathrm{C}=\mathrm{C})$ & $\mathrm{v}(\mathrm{C}-\mathrm{N})$ & $\mathrm{v}(\mathrm{S}-\mathrm{M})$ \\
\hline$[\mathrm{Co}(\mathrm{II})(\mathrm{SD}) \mathrm{PhDTC}]$ & $600,500,480$ & 1145 & 1600 & 1031 & 1480 & 1355 & 977 \\
{$[\mathrm{Ni}(\mathrm{II})(\mathrm{SD}) \mathrm{PhDTC}]$} & $300,253,250$ & 1153 & 1636 & 1092 & 1489 & 1324 & 940 \\
{$[\mathrm{Cu}(\mathrm{II}(\mathrm{SD}) \mathrm{PhDTC})$} & 655,543 & 1140 & 1616 & 1089 & 1486 & 1323 & 938 \\
{$[\mathrm{Zn}(\mathrm{II})(\mathrm{SD}) \mathrm{PhDTC}]$} & - & 1156 & 1592 & 1088 & 1484 & 1278 & 995 \\
{$[\mathrm{Cd}(\mathrm{II})(\mathrm{SD})$ PhDTC $]$} & $510,412,390$ & 1149 & 1580 & 1090 & 1487 & 1337 & 942 \\
SD (Ligand) & $375,335,251$ & - & 1578 & 1081 & 1482 & 1279 & 911 \\
{$[\mathrm{PhDTC}]$ (Ligand) } & $370,340,250$ & - & 1588 & 1081 & 1482 & 1278 & 971 \\
\hline
\end{tabular}

$\mathrm{Zn}(\mathrm{II}), \mathrm{Cd}(\mathrm{II}), \mathrm{Cu}(\mathrm{II}), \mathrm{Ni}(\mathrm{II})$ and $\mathrm{Co}(\mathrm{II})$ complexes respectively. This shift in the absorption band of the free ligand to those observed in the complexes is a result of the coordination between the mixed ligand and the metal ion at the two sulfur atoms of the N-phenyl dithiocarbamate ligand which serve as bidentate sites for the ligand. In the same way, the shift observed at the absorption bands 1588, $1578,1580,1592,1616,1636$ and $1600 \mathrm{~cm}^{-1}$ representing the $\mathrm{v}(\mathrm{N}-\mathrm{H})$ vibrations in the free ligand and the metal complexes respectively is an indication of the coordination that stretches between the nitrogen atoms of the Schiff base ligand to the central metal ion in the respective complexes [15] [16]. In Table 3. the strong bands observed in the free ligands at 971 and $911 \mathrm{~cm}^{-1}$ but with shifts in the bands in the metal complexes at $977,940,938,995,942 \mathrm{~cm}^{-1}$ respectively. The shifts in the bands indicating that coordination of metals to the ligands (M-S), also the new bands appearing between $1145-1156 \mathrm{~cm}^{-1}$ in the metal complexes which is assigned to $\mathrm{S}=\mathrm{O}$, but not found in the free ligands showing the involvement of sulphur atom coordinating to the metal ions [17] [18]. 


\subsection{Antimicrobial Activities}

The data of the antibacterial and antifungi activities of the parent ligands and complexes are given in Table 4 and Table 5. Antimicrobal potentials of metal complexes and the parent ligands have been determined by measuring the diameter of the zone of inhibition. The organisms isolated include Escherichia coli, Proteus vulgaris, Salmonellaus pneumonia, Pseudomonas aeruginosa, Vibro chlolerae and Klebseilla pne typhii, Shigella flexneri, Staphylococcus aureus, Bacillus subtilis, Streptococ umonia bacteria and Fungi isolated are Aspergillus flavus, Mucor mucedo, Aspergillus niger, Candida albicans, Aspergillus flavus, Aspergillus fumigetus, Rhizopus stolon, Mucor mucedo, Monilia amaricana and Candida albicans.

The lowest MIC values of $7.0 \mathrm{~mm}$ and the highest inhibition concentrations 9.5 and $9.0 \mathrm{~mm}$ was observed with the metal complexes against all the bacteria and fungi isolates respectively. The $\mathrm{Cu}(\mathrm{II})$ complex show more antimicrobial activity against the selected pathogens than other metal complexes. Generally, all the metal complexes have performed moderately against both the bacteria and fungi isolates favourably and can be compared with the controls in both the antibacterial and antifungal agents.

The data of the antibacterial and antifungal activities of ligand and complexes are given in Table 4 and Table 5. The data reveals that the complexes have higher inhibitory activities than the free ligand. The enhancement of the activity of ligand on complexation can be explained by Overtone's Concept and Chelation Theory. This theory states that chelation reduces the polarity of the metal atom by the partial sharing of its positive charge with donor groups and possible $\pi$-electron delocalization over the whole ring. This results in increasing lypophilic character of the complex and favours the permeation of the complex through the lipid layer of cell membrane. The complex blocks the metal binding sites in the enzymes of microorganisms. Consequently the complex disturbs the

Table 4. Zone of inhibition in $(\mathrm{mm})$ of the metal complex against various bacteria isolated at $10 \mathrm{mg} / \mathrm{ml}$ concentration.

\begin{tabular}{|c|c|c|c|c|c|c|c|c|c|c|}
\hline Organisms & $\mathrm{Co}(\mathrm{II})$ & $\mathrm{Ni}(\mathrm{II})$ & $\mathrm{Cu}(\mathrm{II})$ & $\mathrm{Zn}(\mathrm{II})$ & $\mathrm{Cd}(\mathrm{II})$ & $\mathrm{SD}$ & PhDTC & Amp & MYCT & DMSO \\
\hline Escherichia coli & 7.5 & 7.5 & 8.5 & 7.5 & 7.5 & 7.0 & 6.0 & 10.0 & 12.0 & NIL \\
\hline Proteus valgaris & 7.5 & 8.5 & 7.5 & 8.0 & 9.0 & 6.0 & 7.0 & 10.0 & 14 & NIL \\
\hline Salmonella typhii & 7.8 & 8.5 & 8.0 & 9.0 & 8.5 & 6.5 & 7.0 & 10.0 & 11.0 & NIL \\
\hline Shigella flexneri & 8.0 & 8.5 & 9.0 & 7.5 & 8.0 & 7.0 & 7.0 & 12.0 & 10.0 & NIL \\
\hline Staphylococcus aureus & 8.5 & 7.0 & 7.5 & 8.5 & 8.0 & 6.0 & 7.0 & 10.0 & 10.0 & NIL \\
\hline Bacillus subtilis & 7.0 & 7.5 & 8.0 & 7.5 & 8.0 & 6.0 & 8.0 & 10.0 & 11.0 & NIL \\
\hline Strepto coccus pneumonia & 7.0 & 8.5 & 9.0 & 7.5 & 8.5 & 6.0 & 7.0 & 10.0 & 12.0 & NIL \\
\hline Psendomonas aeruginosa & 7.5 & 8.0 & 8.0 & 7.0 & 9.0 & 6.5 & 7.0 & 11.0 & 10.0 & NIL \\
\hline Vibro chlolerae & 7.5 & 8.0 & 9.5 & 7.8 & 9.0 & 7.0 & 6.5 & 10.0 & 8.0 & NIL \\
\hline Klebseilla pneumonia & 7.5 & 8.5 & 7.5 & 8.0 & 8.5 & 6.0 & 7.0 & 12.0 & 10.0 & NIL \\
\hline
\end{tabular}


Table 5. Antifungal activity of metal complexes at the minimum inhibitory concentration of $12.5 \mathrm{mg} / \mathrm{ml}$.

\begin{tabular}{|c|c|c|c|c|c|c|c|c|c|c|}
\hline Organisms & $\mathrm{Co}(\mathrm{II})$ & $\mathrm{NI}(\mathrm{II})$ & $\mathrm{Cu}(\mathrm{II})$ & $\mathrm{Zn}(\mathrm{II})$ & $\mathrm{Cd}(\mathrm{II})$ & AMP & MYCO & DMSO & $\mathrm{SD}$ & (PhDTC) \\
\hline Aspergillus flavus & 7.0 & 8.0 & 9.0 & 8.0 & 9.0 & 10.0 & 10.5 & NIL & 6.0 & 7.5 \\
\hline Aspergillus funmigatus & 8.0 & 8.5 & 9.0 & 8.5 & 8.0 & 11.0 & 12.5 & NIL & 7.0 & 7.5 \\
\hline Fusarium solani & 9.0 & 8.5 & 10 & 9.0 & 9.0 & 9.0 & 12.5 & NIL & 7.0 & 6.5 \\
\hline Rhizopus stolon & 7.0 & 8.5 & 9.0 & 8.5 & 8.0 & 10.0 & 10.0 & NIL & NIL & NIL \\
\hline Mucor mucedo & 7.6 & 8.0 & 7.5 & 8.0 & 7.8 & 11.0 & 12.5 & NIL & 6.5 & 6.5 \\
\hline Monilia Americona & 7.0 & 8.0 & 9.0 & 8.0 & 9.0 & 10.0 & 10.8 & NIL & 7.0 & 6.0 \\
\hline Trichoderma Viride & 8.0 & 8.0 & 10.0 & 9.0 & 8.5 & 12 & 10.0 & NIL & 7.5 & 7.0 \\
\hline Saccharo mycodis ludwigii & 7.0 & 8.5 & 10 & 8.5 & 8.0 & 12 & 10.5 & NIL & 7.0 & 6.0 \\
\hline Aspergillus niger & 7.5 & 8.5 & 9.0 & 8.0 & 8.0 & 11 & 7.5 & NIL & 7.5 & 7.5 \\
\hline Candida albicaus & 8.0 & 9.0 & 7.5 & 8.0 & 8.5 & 10 & 10.5 & NIL & 7.0 & 7.0 \\
\hline
\end{tabular}

metabolism pathways in cell, resulting in the extinction of microorganisms [17] [19].

\section{Conclusion}

Mixed ligand complexes of Sulfadiazine Schiff base and Phenyl dithiocarbamates of $\mathrm{Co}(\mathrm{II}), \mathrm{Ni}(\mathrm{II}), \mathrm{Cu}(\mathrm{II}), \mathrm{Zn}(\mathrm{II})$ and $\mathrm{Cd}(\mathrm{II})$ ions have been synthesized and characterized using both the physical and spectroscopic methods. The results obtained so far have indicated that metal complexes are non-polar and non-electrolytes. Metal complexes coordinate through two nitrogen atoms of Sulfadiazine Schiff base and of sulphur atom of Phenyl dithiocarbamate ligands. The antimicrobial studies revealed that metal complexes are more active against the isolated microorganisms than the parent ligands. All the complexes show bacterial and fungal growth inhibition in follow the order: control $>$ metal complexes $>$ parent ligands.

\section{Conflicts of Interest}

The authors declare no conflicts of interest regarding the publication of this paper.

\section{References}

[1] Dhanalaskshmi, M. (2013) Synthesis, Characterization and Antimicrobial Activity of Some Mixed Ligand Metal Complexes. Department of Chemistry, SFR College for Women, Sivakasi, 109-119.

[2] Ejelonu, B.C., Oyeneyin, O.E., Akele, O.E. and Olagboye, S.A. (2018) Synthesis, Characterization and Antimicrobial Properties of $\mathrm{Pd}(\mathrm{II}), \mathrm{Cr}(\mathrm{III}), \mathrm{Ni}(\mathrm{II})$ and $\mathrm{Co}(\mathrm{II})$ Metal Complexes of Aniline and Sulphadiazine Schiff Bases as Mixed Ligands. American Journal of Chemical Research, 2, 1-9.

[3] Chandraleka, S., Chandramohan, G., Dhanasekaran, D., Meenakumari, P. and Panneerselvam, A. (2011) Antifungal Activity of Amino Acid Schiff Base Copper (II) 
Complexes with Phenanthroline and Bipyridyl. International Journal of Chemical and Analytical Science, 2, 1235-1240.

[4] Jameš, D. and Kreft, S. (2008) Salicylaldehyde Is a Characteristic Aroma Component of Buckwheat Groats. Food Chemistry, 109, 293-298.

[5] Saied, M.E.K., Shaker, L.S. and Khaled, A.B. (2001) Schiff Base Complexes Derived from Salicylaldehyde with Amine, $\left[\mathrm{Ni}(1,2-\mathrm{pn})_{2} \mathrm{Cl}_{2}\right] \cdot 3 \mathrm{H}_{2} \mathrm{O}$ and $\left[\mathrm{Cu}(1,2-\mathrm{pn})_{2}\right] \mathrm{SO}_{4} \cdot 2 \mathrm{H}_{2} \mathrm{O}$, as Complex Ligands. Synthesis and Reactivity in Inorganic and Metal-Organic Chemistry, 31, 927-951.

[6] Onwudiwe, C.D. and Ajibade, P.A. (2011) Synthesis, Characterization and Thermal Studies of $\mathrm{Zn}(\mathrm{II}), \mathrm{Cd}(\mathrm{II})$ and $\mathrm{Hg}(\mathrm{II})$ Complexes of $N$-Methyl- $N$-Phenyldithiocarbamate: The Single Crystal Structure of $\left[\left(\mathrm{C}_{6} \mathrm{H}_{5}\right)\left(\mathrm{CH}_{3}\right) \mathrm{NCS}_{2}\right]_{4} \mathrm{Hg}_{2}$. International Journal of Molecular Sciences, 12, 1964-1978.

[7] Manav, N., Mishra, A.K. and Kaushik, N.K. (2004) Triphenyl Phosphine Adducts of Platinum(IV) and Palladium(II) Dithiocarbamates Complexes: A Spectral and in Vitro Study. Spectrochimica Acta Part A: Molecular and Biomolecular Spectroscopy, 60, 3087-3092.

[8] Cohen, S.M. (2007) New Approaches for Medicinal Applications of Bioinorganic Chemistry. Current Opinion in Chemical Biology, 11, 115-120.

[9] Allardyce, C.S., Dorcier, A., Scolaro, C. and Dyson, P.J. (2005) Development of Organometallic (Organo-Transition Metal) Pharmaceuticals. Applied Organometallic Chemistry, 19, 1-10. https://doi.org/10.1002/aoc.725

[10] Casini, A., Gabbiani, C., Sorrentino, F., Rigobello, M.P., Bindoli, A., Gelbach, T.J., Marrone, A., Re, N., Hartinger, C.G., Dyson, P.J. and Messori, L. (2008) Emerging Protein Targets for Anticancer Metallodrugs: Inhibition of Thioredoxin Reductase and Cathepsin B by Antitumor Ruthenium(II)-Arene Compounds. Journal of Medicinal Chemistry, 51, 6773-6781.

[11] Gulcan, M., Sönmez, M. and Berber, I. (2012) Synthesis, Characterization, and Antimicrobial Activity of a New Pyrimidine Schiff Base and Its $\mathrm{Cu}(\mathrm{II}), \mathrm{Ni}(\mathrm{II}), \mathrm{Co}(\mathrm{II})$, Pt(II), and Pd(II) Complexes. Turkish Journal of Chemistry, 36, 189-200.

[12] William, K. (1993) Organic Spectroscopy. 3rd Edition, Macmillan Education Ltd., London.

[13] Nakamoto, K. (1978) Infrared and Raman Spectra of Inorganic Coordination Compounds. 3rd Edition, Wiley, New York.

[14] Ajibade P.A., Kolawole, G.A. and O’Brien, P. (2007) Metal Complexes of 4-Amino-N-(2-Pyrimidinyl) Benzene Sulfonamide: Synthesis, Characterization and Antiprotozoal Studies. Synthesis and Reactivity in Inorganic, Metal-Organic, and Nano-Metal Chemistry, 37, 653-659.

[15] Ajibade, P.A. and Kolawole, G.A. (2008) Synthesis, Characterization, Antiplasmodial and Antitrypanosomal Activity of Some Metal (III) Complexes of Sulfadiazine. Bulletin of the Chemical Society of Ethiopia, 22, 261-268.

[16] William, D.H. and Fleming, I. (1989) Spectroscopic Methods in Organic Chemistry. 3rd Edition, McGraw-Hill Book Company, New York, London.

[17] Shaker, S.A., Mohammed, H.A. and Salih, A.A. (2010) Preparation, Physio-Chemical and Spectroscopic Investigation of Thiacetazone Quinalizorine Complexes with $\mathrm{Mn}(\mathrm{II}), \mathrm{Fe}(\mathrm{II}), \mathrm{Co}(\mathrm{II}), \mathrm{Ni}(\mathrm{II}), \mathrm{Cu}(\mathrm{II}), \mathrm{Zn}(\mathrm{II}), \mathrm{Cd}(\mathrm{II})$ and $\mathrm{Pd}(\mathrm{II})$. Australian Journal of Basic and Applied Sciences, 10, 5178-5183.

[18] Abdul-Ghani, A.J. and Khaleel, A.M.N. (2009) Synthesis and Characterization of New Schiff Bases Derived from N (1)-Substituted Isatin with Dithiooxamide and 
their $\mathrm{Co}(\mathrm{II}), \mathrm{Ni}(\mathrm{II}), \mathrm{Cu}(\mathrm{II}), \mathrm{Pd}(\mathrm{II})$, and $\mathrm{Pt}(\mathrm{IV})$ Complexes. Bioinorganic Chemistry and Applications, 2009, Article ID: 413175.

[19] Srivastava, R.S. (1997) Studies on Some Antifungal Transition Metal Chelates of 2-(2-Hydroxybenzylideneamino) Benzimidazole. Indian Journal of Chemistry, 29, 1024 . 